\title{
MAGNETIC FIELD AND GIBBERELIC ACID AS PRE-GERMINATION TREATMENTS OF PASSION FRUIT SEEDS
}

\author{
Renata Diane Menegatti ${ }^{1}$, Luana Oliveira de Oliveiraa ${ }^{1}$, Ádrya Vanessa Lira da Costa ${ }^{1}$, Eugenia Jacira \\ Bolacel Braga ${ }^{1}$, Valmor João Bianchi ${ }^{1}$
}

${ }^{1}$ University Federal of Pelotas, Institute of Biology, Department of Botany - Campus Universitário, Capão do Leão - RS, 96010900

Autor para correspondência: Renata Diane Menegatti, renata.d.menegatti@gmail.com

\begin{abstract}
The aim of this study was to evaluate the effect of pre-germination treatments (magneto-priming and immersion of seeds in gibberellic acid solution) on variables associated with germination, emergence and vigor of Passiflora edulis seeds 'BRS Gigante Amarelo' cultivar. Seeds were extracted from fruits, washed, immersed for 6 hours in solutions with different $\mathrm{GA}_{3}$ concentrations and later arranged in a circular form in Petri dishes at temperature of $25^{\circ} \mathrm{C}$, with and without exposure to magnetic field. Subsequently, analyses associated with the germination and emergency test were carried out. The experimental design was completely randomized design, with $3 \times 2$ factorial, three $\mathrm{GA}_{3}$ concentrations $\left(0,50\right.$ and $\left.100 \mathrm{mg} \mathrm{L}^{-1}\right)$ and presence/absence of magnetic field (MF), with four replicates of 20 seeds each. Variables germination percentage, germination speed index, mean germination time, percentage of emerged seedlings, emergence speed index, shoot length and root length and seedling dry weight were evaluated. Results indicate that the exposure of passion fruit seeds to MF in an isolated way stimulates seed germination, emergence and vigor, being an alternative to conventional treatments based on chemical substances.
\end{abstract}

KEYWORDS: Passiflora edulis, magneto-priming, plant growth regulator, germination.

\section{CAMPO MAGNÉTICO E ÁCIDO GIBERÉLICO COMO MÉTODOS PRÉ-GERMINATIVOS DE SEMENTES DE MARACUJAZEIRO}

RESUMO: Propôs-se, neste estudo, avaliar o efeito dos tratamentos pré-germinativos (magneto-priming e ácido giberélico) sobre variáveis associadas à germinação, emergência e vigor de sementes de Passiflora edulis cv. 'BRS Gigante Amarelo'. As sementes foram extraídas dos frutos, lavadas, imersas durante 6 horas, em soluções de $\mathrm{GA}_{3}$ e, posteriormente, foram dispostas de forma circular em placas de petri, sob temperatura de $25^{\circ} \mathrm{C}$, com e sem exposição a campo magnético. Após realizou-se análises associadas ao teste de germinação e de emergência. 0 delineamento experimental utilizado foi o inteiramente casualizado, em esquema fatorial 3x2, três concentrações de $\mathrm{GA}_{3}\left(0 ; 50\right.$ e $\left.100 \mathrm{mg} \mathrm{L}^{-1}\right)$ e presença/ausência de campo magnético $(\mathrm{CM})$, com quatro repetições de 20 sementes cada. Foram avaliadas as variáveis porcentagem de germinação, índice de velocidade de germinação, tempo médio de germinação, porcentagem de plântulas emergidas, índice de velocidade de emergência, comprimento da parte aérea e raiz e massa seca de plântulas. Os resultados obtidos indicaram que a exposição das sementes de maracujazeiro ao $\mathrm{CM}$, de forma isolada, estimula a germinação, emergência e vigor das sementes, além de representar uma alternativa aos tratamentos convencionais baseados em substâncias químicas.

PALAVRAS CHAVE: Passiflora edulis, magneto-priming, reguladores vegetais, germinação.

\section{INTRODUCTION}

Plants are commonly used as models for the characterization of biological responses in relation to the exposure to various physical factors, such as microwave irradiation (MW), ultraviolet radiation (UV), ionizing radiation (IR) and others (Araújo et al., 2016).
In the last years, studies have suggested the positive action of magnetic field (MF), promoting the germination of seeds of agricultural interest and reducing the time of seedling emergence (Afzal et al., 2012; Zia et al., 2012; Iqbal et al., 2016; Baghel et al., 2016; Baghel et al., 2017). Thus, studies aimed at a 
better understanding of the effects of exposure to MF from objects such as magnets or electromagnets are of great relevance for seed physiology (Belyavskaya, 2004; Silva and Dobranszki, 2016).

Pre-germination treatment based on seed exposure to MF is called magneto-priming and has the purpose of promoting seed germination and vigor, as well as increasing the yield of the most varied crops (Aguilar et al., 2009; Rathod and Anand, 2016). This physical method, in addition to providing higher germination, vigor and yield performance of some crops, represents a viable alternative to conventional chemical-based treatments such as plant growth regulators, which are costly and difficult to handle by farmers (Aladjadjiyan, 2012; Araújo et al., 2016).

The magneto-priming technique used in soybean seeds, an agricultural crop of great importance in the country, increased germination speed compared to control treatment (no exposure of seeds to MF), suggesting a certain influence of MF in the processes of water absorption by seeds, such as stabilization of water $\mathrm{pH}$, which in the absence of MF, presented unstable $\mathrm{pH}$, a fact that may have resulted in increased speed and uniformity of the germination process (Torres-Osório et al., 2006).

The $\mathrm{pH}$ stability of water absorbed by seeds may have been achieved due to the alteration of its ionicity, resulting from the breakage of hydrogen bonds present in the molecule, which allowed water to present higher concentration of free ions. The exposure of water to a magnetic field results in alterations of its basic properties such as $\mathrm{pH}$ and ionic strength, providing greater movement capacity (Tai et al., 2008). In addition, MF directly acts under the cell membrane structure, making it more permeable to the movement of ions and water, thus accelerating the stage of water absorption by seeds, where metabolic processes necessary for germination are activated, resulting in satisfactory germination rate (Bhardwaj et al., 2012).

The alteration of the water properties (with greater circulation capacity) and the possible action on the cell membrane permeability allow elucidating the mechanism of action of the magnetic field on seed germination promotion. Carvalho and Nakagawa (2012) suggest that the action of MF occurs during the initial stage of the germination process, in which water absorption takes place to resume the embryonic axis growth.

One of the main obstacles in the production of passion fruit seedlings is tegument dormancy, a fact that makes it difficult for water to enter the plant organ, prolonging the resumption of embryo development, resulting in irregular and unsatisfactory germination rate (Lima, 2002). As a result, several studies have been carried out testing pre-germination treatments for promotion and uniformity of the germination of passion fruit seeds.

Some treatments have shown to be satisfactory in breaking the dormancy of passion fruit seeds, among them the immersion of seeds in different gibberellic acid concentrations $\left(\mathrm{GA}_{3}\right)$ for certain periods (Rossetoet et al., 2000; Lima et al., 2009). $\mathrm{GA}_{3}$ is a growth regulator indicated to accelerate and standardize germination by promoting the synthesis of enzymes that digest reserves stored in the endosperm, such as starch, which will be used to accelerate and standardize the germination process (Taiz and Zeiger, 2017).

In Passiflora edulis seeds (yellow passion fruit) immersed in gibberellic acid solution at different concentrations, Santos et al. (2013) found that pretreatment with $100 \mathrm{mg} \mathrm{L}^{-1} \mathrm{GA}_{3}$ solution for six hours stimulated seed germination and promoted beneficial effects on the vigor of passion fruit seedlings.

No studies showing the effects of the application of magnetic field alone, or combined with the use of $\mathrm{GA}_{3}$ on seed germination and seedling emergence have been found in literature. In this way, the aim of this work was to evaluate the combined or isolated effects of gibberellic acid and MF on germination, emergence and vigor of $P$. edulis seeds.

\section{MATERIAL AND METHODS}

Hybrid passion fruit seeds ( $P$. edulis 'BRS Gigante Amarelo') were used as experimental material, provided by 'Embrapa Clima Temperado' (Pelotas, RS, Brazil). Seeds were extracted from fruits, manually washed in running water with the aid of a sieve to remove aryl and impurities, and then dried with paper towels and kept for 24 hours at room temperature.

After this procedure, the water content of seeds was determined by the greenhouse method at 105 $\pm 3^{\circ} \mathrm{C}$, for $24 \mathrm{~h}$, according to Brasil (2009), using four replicates of 20 seeds.

For the germination test, passion fruit seeds were immersed for 6 hours in solutions containing different gibberellic acid concentrations $\left(\mathrm{GA}_{3}\right)(0,50$ and $\left.100 \mathrm{mg} \mathrm{L}^{-1}\right)$. Subsequently, seeds were arranged 
in a circular form on Petri plates on two germitest paper sheets moistened with amount of water equivalent to 2.5 times the mass of the non-hydrated paper.

Treatments that received MF had in the center of the circle a neodymium magnet of $200 \mathrm{mT}$ (megaTesla) with the south pole facing up during the germination test (14 days). Petri dishes were then conducted and kept in BOD type chamber (Biological Oxygen Demand), containing fluorescent lamps and $12 \mathrm{~h}$ photoperiod at constant temperature of $25^{\circ} \mathrm{C}$, according to instructions described by Brasil (2009) for the conduction of germination tests.

The experimental design was completely randomized, in a $3 \times 2$ factorial scheme, involving three gibberellic acid concentrations $\left(0,50\right.$ and $\left.100 \mathrm{mg} \mathrm{L}^{-1}\right)$ and presence and absence of magnetic field (MF), and those with the presence of MF received a $200 \mathrm{mT}$ neodymium magnet at the center of the Petri dish during the entire germination test, totaling six treatments, with four replicates of 20 seeds per treatment.

Germinated seeds were daily evaluated using root protrusion as a germination criterion, about $2 \mathrm{~mm}$ in length (Brazil, 2009). The germination test was finished at 14 days, after three consecutive evaluations, and no new germinated seeds were observed.

After the germination period (14 days), germinated seeds were transplanted into 72-cell polystyrene trays (114 $\mathrm{cm}^{3}$ per cell), containing a compound of $25 \%$ orchard soil $+25 \%$ vermiculite + $25 \%$ regular sand +25 commercial substrate (Carolina Soil) as substrate and kept in greenhouse for the period necessary for at least one of the treatments to achieve $75 \%$ seedling emergence ( 21 days).
Emerged seedlings were daily evaluated up to 21 days when the experiment was finished and seedlings were measured for shoot and root length $(\mathrm{cm})$ with the aid of a graduated ruler. Subsequently, seedlings were dried in a forced air circulation oven at $70^{\circ} \mathrm{C}$ for 72 hours until constant mass for the individual determination of the total dry mass.

Germination percentage ( $\%$ GER), germination speed index (GSI), mean germination time (MGT, in days), percentage of emerged seedlings (\% ES), emergence speed index (ESI), shoot length (SL, in $\mathrm{cm}$ ), root length $(R L$, in $\mathrm{cm})$, and total seedling dry mass (SDM, in grams) were determined.

Data were tested for homogeneity (Bartlett) and abnormality (Shapiro-Wilks) and after meeting assumptions, they were submitted to analysis of variance. If there were significant differences, means were compared by the Tukey test at $5 \%$ error probability. All analyses were performed using the Sisvar statistical software (Ferreira, 2011).

\section{RESULTS AND DISCUSSION}

The initial mean water content of seeds at the time of the germination test was $9.2 \%$, sufficient to maintain the germination capacity of passion fruit seeds (Fonseca and Silva, 2005).

According to the analysis of variance, it was possible to verify that there was no significant interaction between factors $\left(\mathrm{GA}_{3}\right.$ concentration and presence/ absence of MF) for all variables tested (Table 1), therefore evaluating the effect of each factor in isolation. It was also verified that variables mean germination time (MGT), shoot length (SL) and total seedling dry mass (SDM) did not present significant differences as a function of treatments.

Table 1. Analysis of variance for the following variables: Germination percentage ( $\%$ GER), germination speed index (GSI), mean germination time (MGT, in days), percentage of emerged seedlings (\% ES), emergence speed index (ESI), shoot length (SL in $\mathrm{cm}$ ), root length (RL in $\mathrm{cm}$ ), and total seedling dry mass (SDM, in grams) of Passiflora eduli seeds 'BRS Gigante Amarelo' cultivar submitted to pre-germination treatments of seed immersion in gibberellic acid solution $\left(\mathrm{GA}_{3}\right)$ and magneto-priming (MF). Pelotas, RS, 2017.

\begin{tabular}{|c|c|c|c|c|c|c|c|c|c|}
\hline \multirow{2}{*}{ Source of Variation } & \multirow{2}{*}{ DF } & \multicolumn{8}{|c|}{ Average Square } \\
\hline & & $\% \mathrm{G}$ & $\overline{G S I}$ & MGT & $\% \mathrm{ES}$ & ESI & $\overline{S L}$ & $\mathrm{RL}$ & $\overline{S D M}$ \\
\hline $\mathrm{GA}_{3}$ concentration & 2 & $762.5^{*}$ & $24.0^{*}$ & $1.86^{\mathrm{ns}}$ & $546.8^{*}$ & $31.62^{*}$ & $0.38^{\text {ns }}$ & $0.29^{*}$ & $0.004^{\text {ns }}$ \\
\hline MF (MF) & 1 & $2400.0^{*}$ & $30.17^{*}$ & $17.2^{\mathrm{ns}}$ & $301^{\text {ns }}$ & $15.15^{*}$ & $0.05^{\text {ns }}$ & $0.07^{\text {ns }}$ & $0.023^{\text {ns }}$ \\
\hline $\mathrm{GA}_{3} \times \mathrm{MF}$ & 2 & $12.5^{\text {ns }}$ & $0.28^{\mathrm{ns}}$ & $1.41^{\mathrm{ns}}$ & $19.8^{\text {ns }}$ & $0.45^{\mathrm{ns}}$ & $0.65^{\mathrm{ns}}$ & $0.05^{\mathrm{ns}}$ & $0.004^{\text {ns }}$ \\
\hline Residue & 18 & & & & & & & & \\
\hline Mean & & 55 & 4.97 & 4.53 & 65 & 6.28 & 3.63 & 3.58 & 0.34 \\
\hline VC (\%) & & 22.68 & 28.9 & 16.8 & 13.6 & 28.7 & 9.52 & 7.35 & 25.4 \\
\hline
\end{tabular}

* e ns: significant and non significant, respectively, at $5 \%$ error probability level. 
For variable germination percentage, there was an isolated effect of both factors. In the pre-germination treatments of seeds with gibberellic acid solution, treatment with absence of $\mathrm{GA}_{3}$ was superior to the other concentrations tested (50 and $100 \mathrm{mg} \mathrm{L}^{-1}$ ) and promoted similar responses, not differing from each other (Figure 1A). Evaluating the effect of pre-germination magnetopriming treatment, it was verified that the presence of MF provided mean germination percentage 30.7\% higher in relation to the absence of MF (Figure 1B).

Figure 1. Germination percentage ( $\% \mathrm{G})$ of Passiflora eduli seeds 'BRS Gigante Amarelo' cultivar as a function of the effect of pre-germination treatments of seed immersion in gibberellic acid solution (A) and magneto-priming (B). Pelotas, RS, 2017.

A

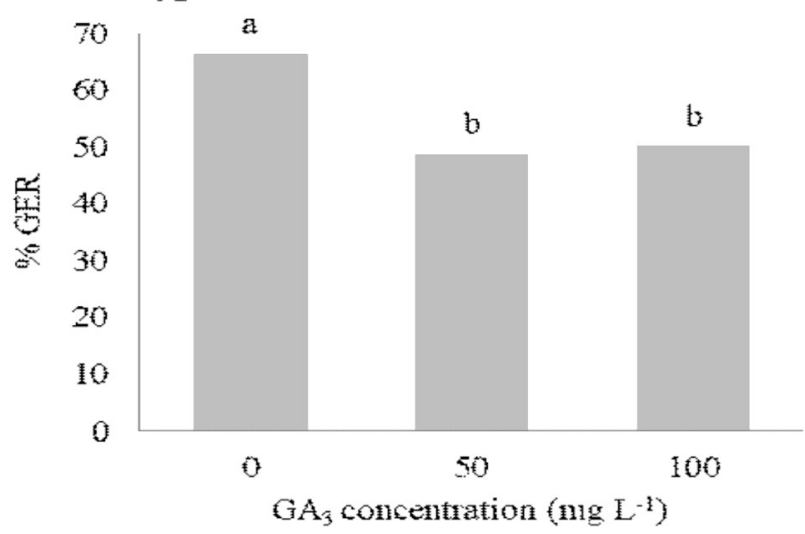

$\mathrm{B}$

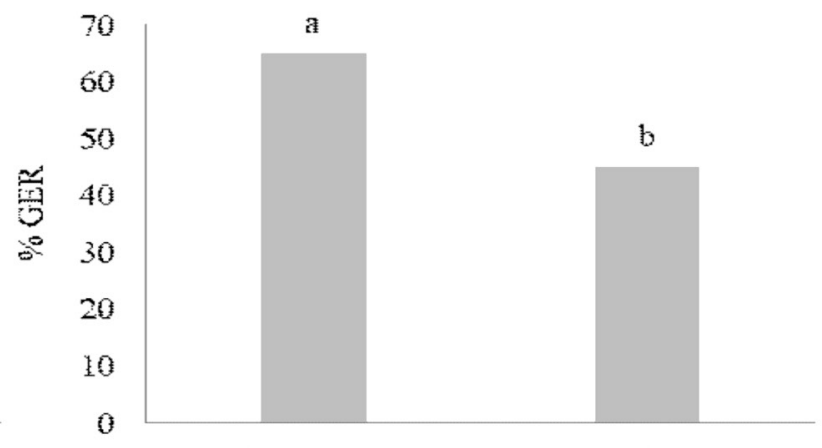

Maguetic field

Means followed by the same letter do not differ by the Tukey's test at $5 \%$ probability.

Using the magneto-priming technique as pregermination treatment, Poinapen et al. (2013) and Torres-Osório et al. (2015) observed that tomato and soybean seeds, as well as in this work, presented seed germination rate of up to twice higher than that obtained for control (absence of MF exposure).

These results support the hypothesis suggested by Tai et al. (2008) that the exposure of seeds to a magnetic field increases the capacity of water movement in the substrate and inside the organ, facilitating the imbibition process and promoting the resumption of the embryo growth and development more quickly.

The germination speed is indicated by the germination speed index (GSI), and as can be observed in Figure 2B, GSI was 36.94\% higher in seeds submitted to pre-germination magneto-priming treatment. ESI was $22.34 \%$ higher in treatment with MF compared to control without MF (Figure 2D). For variable $\% \mathrm{G}$, treatment with absence of $\mathrm{GA}_{3}$ resulted in values considered to be satisfactory and statistically superior for variables GSI and ESI, when compared to those who received immersion in $100 \mathrm{mg} \mathrm{L}^{-1} \mathrm{GA}_{3}$ solution (Figure 2A and $2 \mathrm{C}$ ).

Figure 2. Germination speed index (GSI) and emergence speed index (ESI) of Passiflora eduli seeds 'BRS Gigante Amarelo' cultivar as a function of the effect of pre-germination treatments, seed immersion in acid gibberellic solution ( $A$ and $C$ ) and magneto-priming (B and D), respectively. Pelotas, RS, 2017. Averages followed by the same letter do not differ from each other by the Tukey test at $5 \%$ probability.
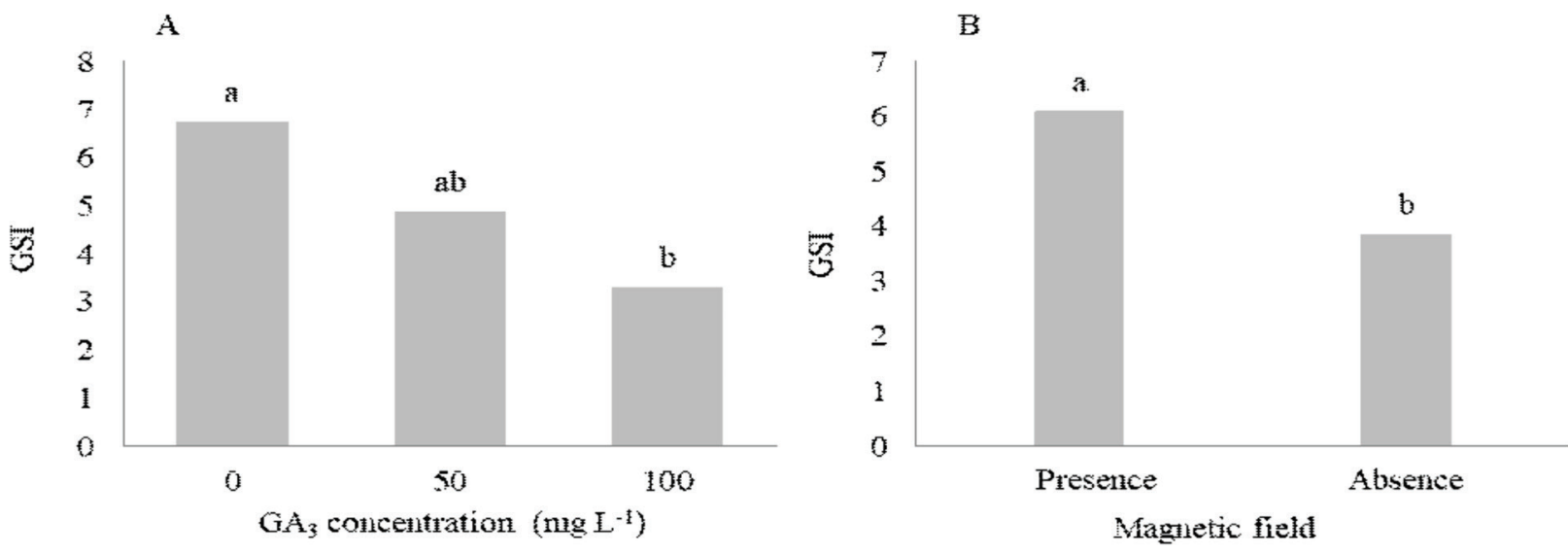


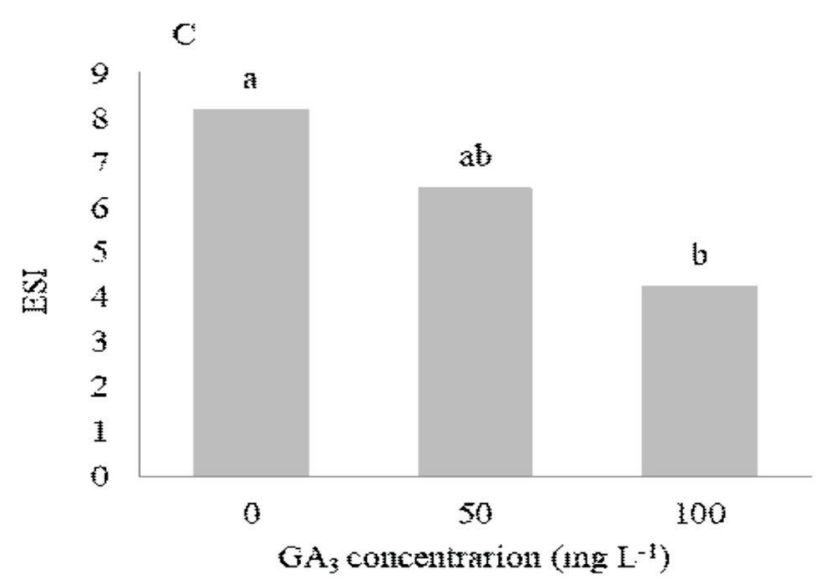

In cucumber seeds (Cucumis sativus) exposed to $200 \mathrm{mT} \mathrm{MF}$ (same intensity used in the present study), Bhardwaj et al. (2012) observed higher germination potential and GSI compared to control (without exposure to MF), attributing this superiority to the action of MF on the structure of cell membranes. The authors suggested that MF may have influenced the permeability of cell membrane membranes, facilitating the transport of ions

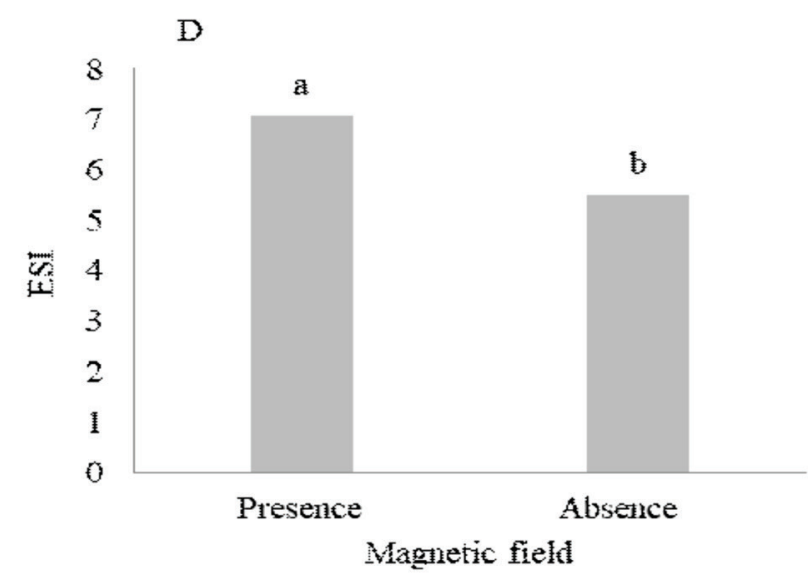

and water, accelerating the stages of the germination process and thus increasing seed vigor.

Results similar to those found for variables directly related to germination were also obtained for root length ( $R L$ ) (Figure 3B) and for the percentage of emerged seedlings (\% ES), which in treatments without gibberellin acid was higher than doses of 50 and 100 $\mathrm{mg} \mathrm{L}^{-1}$, which did not differ from each other (Figure 3A).

Figure 3. Percentage of emerged seedlings (\% ES) (A) and root length $(R L)(B)$ of Passiflora eduli seeds 'BRS Gigante Amarelo' cultivar as a function of pre-germination effect, seed immersion in gibberellic acid solution. Pelotas, RS, 2017. Averages followed by the same letter do not differ from each other by the Tukey test at $5 \%$ probability.

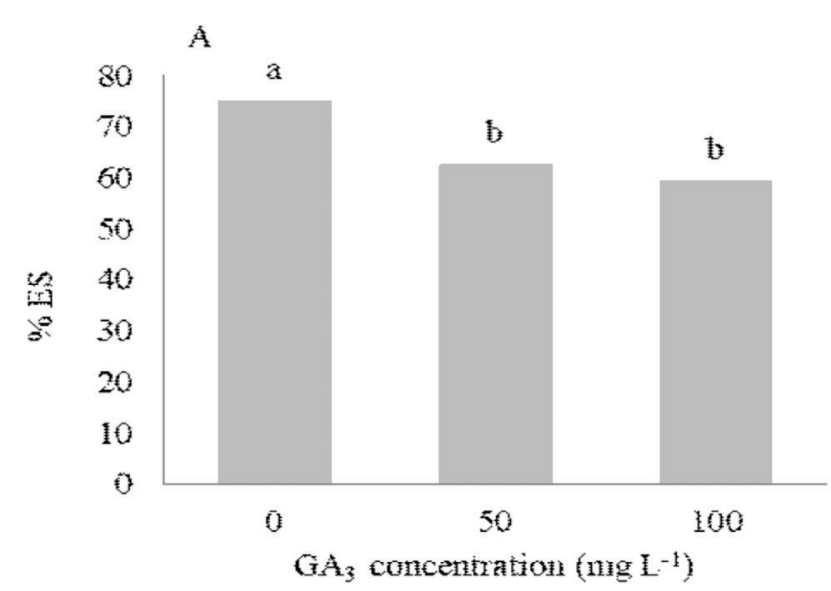

In general, all variables that presented significant differences for pre-germination treatment through the immersion of seeds in gibberellic acid solution resulted in superior performance in treatment without $\mathrm{GA}_{3}$, suggesting that even in the presence of the hormone responsible for the synthesis of alpha-amylase enzyme, which acts on the starch hydrolysis in the seed endosperm, providing energy compounds essential for embryo growth and development, germination may have been limited by the seed tegument dormancy, making

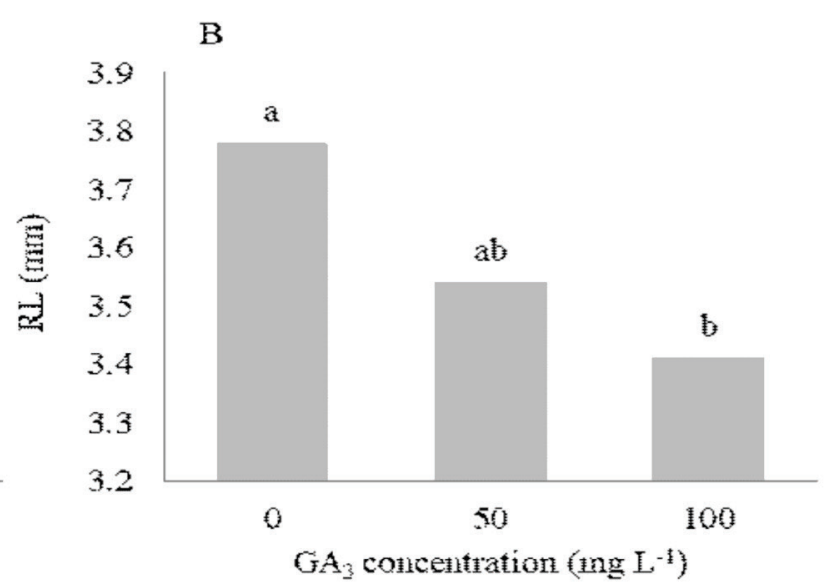

water absorption difficult, as well as the hormone itself (Ataíde et al., 2016; Pedroso et al., 2016).

It is known that the initial stage of the germination process occurs with water absorption during the imbibition process, which will allow the rehydration of tissues and the reactivation of the cellular metabolism, as well as the activation of enzymes that participate in the respiratory process, intensifying it (Carvalho and Nakagawa, 2012). After initiation of imbibition and acceleration of the cell metabolism, 
enzymes responsible for the degradation of energy reserves present in the endosperm are synthesized and the products of their activity will be used to provide the energy necessary for the resumption of the embryonic axis growth, that is, for germination (Taiz and Zeiger, 2017).

Therefore, the alteration of the water properties and the possible increase in the permeability of membranes, facilitating the process of water absorption by seeds could explain the mechanism of action of the magnetic field on the promotion of seed germination.

The low germination of physiologically mature passion fruit seeds can be attributed to the presence of tegument dormancy, which limits the entry of water into the seed, controlling the embryonic axis development and the balance between promoting and inhibiting substances (Lima, 2002).

Similar results were found by Zucareli et al. (2003), who tested the application of gibberellin acid in Passiflora alata seeds, another species of the genus Passiflora, and concluded that the growth regulator did not favor the seed germination process. They concluded that the germination performance was limited due to hormonal imbalance promoted by the application of plant regulators at doses inadequate to the species.

It is noteworthy that the concentrations tested in the present study were based on a study carried out by Santos et al. (2013), who verified that pre-treatment of $P$. edulis seeds with $100 \mathrm{mg} \mathrm{L}^{-1} \mathrm{GA}_{3}$ concentration for six hours maximized seed germination, but this is another passion fruit cultivar, and thus the unsatisfactory results obtained can be attributed to both the gibberellic acid concentrations used and the time of seed immersion, reinforcing the need for further studies.

In relation to the potential of MF to change the properties of water to make itmore mobile and improve its action on the permeability of cell membranes, facilitating the transport of ions and water, it is noteworthy that the exposure of $P$. eduli seeds 'BRS Gigante Amarelo' cultivar to MF (of $200 \mathrm{mT}$ ) provided higher performance regarding seed germination, emergence and vigor when compared to the other treatments.

Therefore, this study highlights the magnetopriming physical method as a promising alternative and viable technique for the pre-germination treatment of passion fruit seeds and brings important information for the field of seed technology, since the results confirm the higher germination and vigor of seeds exposed to MF, offering advantages over conventional treatments based on chemical substances, because it is a non-invasive, ecologically correct and easy-toapply technique (Araújo et al., 2016).

Although it is a recently explored technique, pregermination magneto-priming treatment has commercial scale applicability already described for considerable amounts of seeds from the use of electromagnetic field generators, such as the Testron EM-20 (Testron Instruments, Delhi, India), manufactured to promote the germination of soybeans in order to supply extensive agricultural crops (Vashisth and Nagarajan, 2008).

In view of the above, it could be concluded that the pre-germinating magneto-priming treatment using $200 \mathrm{mT}$ magnetic field is the most efficient in promoting germination, emergence and vigor of passion fruit seeds 'BRS Gigante Amarelo' cultivar.

\section{REFERENCES}

Afzal, I.; Mukhtar, K.; Qasim, M.; Basra, S. M. A.; Shahid, M.; Haq, Z. Magnetic stimulation of marigold seed. Int. Agrophysics, 2012, 26, 3, 335-339.

Aguilar, C. H.; Dominguez-Pacheco, A.; Carballo, A. C.; Cruz-Orea, A.; Ivanov. R.; Bonilla, J. L. L. Alternating magnetic field irradiation effects. Acta Agrophys, 2009, $14,7-17$

Aladjadjiyan, A.

Physicalfactorsforplantgrowthstimulation improve food quality. Food Production-Approaches, 2012,145-168.

Araujo, S. de S.; Paparella, S.; Dondi, D.; Bentivoglio, A.; Carbonera, D.; Balestrazzi, A. Physical Methods for Seed Invigoration: Advantages and Challenges in Seed Technology. Front Plant Science, 2016, 7, 646.

Ataíde, G. da M.; Borges, E. E. de L.; Leite Filho, A. T. Alterações fisiológicas e biométricas em sementes de Melanoxylon brauna Schott durante a germinação em diferentes temperaturas. Revista Árvore, 2016, 40, 1.

Baghel, L.; Kataria, S.; Guruprasad, K. N. Static magnetic field treatment of seeds improves carbon and nitrogen metabolismo under salinity stress in soybean. Bioelectromagnetics, 2016, 37, 455-470. 
Baghel, L.; Kataria, S.; Guruprasad, K.N. Effect of static magnetic field pretreatment on growth, photosynthetic performance and yield of soybean under water stress. Photosynthetica, 2017, 55, 1-13.

Belyavskaya, N.A. Biological effects due to weak magnetic field on plants. Advances Space Research, 2004, 34, 1566-1574.

Bhardwaj, J.; Anan, A.; Nagarajan, S. Biochemical and biophysical changes associated with magnetopriming in germinating cucumber seeds. Plant Physiology and Biochemistry, 2012, 57, 67-73.

Bilalis, D. J.; Katsenios, N.; Efthimiadou, A.; Karkanis, A; Efthimiadis, P. Investigação do campo eletromagnético pulsado como novo método orgânico de pré-semeadura nas fases de germinação e crescimento inicial do algodoeiro. Eletromagnetic Biology and Medicine, 2012, 31, 143-150.

Brasil. Ministério da Agricultura, Pecuária e Abastecimento. Regras para análise de sementes. Ministério da Agricultura, Pecuária e Abastecimento. Secretaria de Defesa Agropecuária. Brasília, DF: Mapa/ ACS, 2009, 395p.

Carvalho, N. M. de; Nakagawa, J. Sementes: ciência, tecnologia e produção. 5. ed. Jaboticabal: Funep, 2012, $590 \mathrm{p}$.

Ferreira, D. F. SISVAR: um sistema de análise estatística de computadores. Ciência e Agrotecnologia, 2011, 35, 6, 1039-1042.

Fonseca, S. C. L.; Silva, W. R. da. Conservação de sementes de maracujá-amarelo: interferências do teor de água das sementes e da temperatura de armazenamento. Bragantia, 2005, 64, 2, 273-289.

Generoso, T. N.; Martinez, M. A.; Rocha, G. C.; Hamakawa, P. J. Magnetização da água e parâmetros de transporte de fósforo no solo. Revista Brasileira de Engenharia Agrícola e Ambiente, 2017, 21,1.

Iqbal, M.; Haq, Z.; Malik, A.; Ayub, C. M.; Jamil, Y.; Nisar, J. Pre-sowing seed magnetic field stimulation: a good option to enhance bitter gourd germination, seedling growth and yield characteristics. Biocatalysis
Agricultural Biotechnology, 2016, 5, 30-37.

Lima, A. de A. Maracujá produção: introdução. In: LIMA, A. de A. Maracujá produção: aspectos técnicos. Brasília: Embrapa. Informação Tecnológica, 2002, 209p.

Lima, C. S. M.; Betemps, D.L.; Tomaz, Z.F.P.; Galarça, S.P.; Rufato, A.R. Germinação de sementes e crescimento de maracujá em diferentes concentrações do ácido giberélico, tempos de imersão e condições experimentais. Revista Brasileira de Agrociência, 2009, $15,43-48$.

Pedroso, L.; Bertoldo, J. L.; Marchi, B. de A.; Cruz, R. M. S. da; Souza, B. C. de; Lermen, C.; Alberton, O. Avaliação dos fitorreguladores auxina e giberelina na germinação e crescimento do arroz. Arquivos de Ciências Veterinárias e Zoologia, 2016, 19, 4, 241-245.

Poinapen, D.; Brown, D. C. W.; Beeharry, G. K. Seed orientation and magnetic field strength have more influence on tomato seed performance than relative humidity and duration of exposure to non-uniform static magnetic fields. Journal Plant Physiology, 2013, 170, 1251-1258.

Rajendra, P. H.; Nayak, S.; Sashidhar, R. B.; Subramanyam, C.; Devendarnath, D.; Gunasekaran, B.; Aradhya, R. S. S.; Bhaskaran, A. Effects of power frequency electromagnetic fields on growth of germinating Vicia faba L., the broad bean. Eletromagnetic Biology and Medicine, 2005, 24, 39-54.

Rathod, G. R.; Anand, A. Effect of seed magneto-priming on growth, yield and $\mathrm{Na} / \mathrm{K}$ ratio in wheat (Triticum aestivum L.) under salt stress. Industrial Journal Plant Physiology, 2016, 21, 1, 15-22.

Rosseto, C. A. V; Coneglian, R. C. C.; Nakagawa, J.; Shimizu, M. K.; Marin, V. A. Germinação de sementes de maracujá-doce (Passiflora alata Dryand) em função de tratamento pré-germinativo. Revista Brasileira de Sementes, 2000, 22, 1,247-252.

Santos, C. A. C.; Vieira, E. L.; Peixoto, C. P.; Ledo, C. A. S. Germinação de sementes e vigor de plântulas de maracujazeiro amarelo submetidos à ação do ácido giberélico. Bioscience Journal, 2013, 29, 400-407. 
Silva, J.A.T.; Dobranszki, J. Magnetic fields: how is plant growth and development impacted. Protoplasma, 2016, 253, 231-248.

Tai, C. Y.; Wu, C.; Chang, M. Effects of magnetic field on the crystallization oc calcium carbonate using permanent magnets. Chemical Engineering Science, 2008, 63, 5606-5612.

Taiz, L.; Zeiger, E. Fisiologia vegetal. 6. ed. Porto Alegre: Artmed, 2017, 954 p.

Torres-Osorio, J. I.; Aranzazu-Osorio, J. E.; CarbonellPadrino, M. V. Static homogeneous magnetic field effects on germination and water absorption in soybean seeds. Tecnológicas, 2015, 18, 35, 11-20.
Vashisth, A.; Nagarajan, S. Exposure of seeds to static magnetic field enhances germination and early growth characteristics in chickpea (Cicer arietinum L.). Bioelectromagnetics, 2008, 29, 571- 578.

Zia, U. L.; Haq, Z.; Jamil, Y.; Irum, S.; Randhawa, M. A.; Iqbal, M.; Amin, N. Enhancement in the germination, seedling growth and yield of radish (Raphanus sativus) using seed pre-sowing magnetic field treatment. Polish Journal Environmental Studies, 2012, 21, 369-374.

Zucareli, C.; Castro, M.M.; Oliveira, H.R.; Brancalião, S.R.; Rodrigues, J.D.; Ono, E.O.; Boaro, C.S.F. Fitoreguladores e germinação de sementes de maracujá doce em condições de laboratório. Scientia Agrária, 2003, 4, 9-14. 